\title{
Endophthalmitis due to caterpillar setae: surgical removal and electron microscopic appearances of the setae
}

\author{
CAROLINE STEELE,' D. R. LUCAS, ${ }^{2}$ And A. E. A. RIDGWAY' \\ From the 'Manchester Royal Eye Hospital and the ${ }^{2}$ Departments of Ophthalmology and Pathology, \\ University of Manchester
}

SUMmary A case of endophthalmitis due to caterpillar setae was, for the first time, successfully treated by surgical removal of the setae. The procedure was facilitated by the use of sodium hyaluronidate. Scanning and transmission electron microscopy of the setae showed evidence of enzymatic degradation of the shaft and burial of the spines in exudate.

The dermal reaction to sharp and irritant caterpillar setae was known to the Greeks and the Romans, and was commented on by Dioscorides and Pliny.' The first scientific reference to the dermatitis in English seems to be that of Sir Joseph Banks, PRS, ${ }^{2}$ written within a month of the discovery of Australia by Captain Cook's expedition. He noted that at Bustard Bay:

'The mangroves also had another trap which most of us fell into, a small kind of caterpillar, green and beset with many hairs: these sat upon the leaves many together ranged by the side of each other like soldiers drawn up, 20 or 30 perhaps upon one leaf; if these wonderful militia were touched but ever so gently they did not fail to make the person offending them sensible of their anger, every hair of them stinging much as nettles do, but with a more acute though lasting smart.'

The dermatitis, which has been well documented, ${ }^{3}$ is seasonally endemic in the pine forested areas of Europe $^{4}$ and is an occupational disease amongst tea planters in Pakistan. ${ }^{5}$

The ocular manifestations, which have been reported extensively since the original description of Ophthalmia nodosa by Pagenstecher, ${ }^{6}$ have been reviewed comprehensively by Gundersen et $\mathrm{al}^{7}$

\section{Case report}

In July 1982 a hairy caterpillar was forcibly blown through a hollow tent pole into the eye of a boy aged 9. He experienced immediate irritation for which he

Correspondence to Mr A. E. A. Ridgway, Manchester Royal Eye Hospital, Oxford Road, Manchester, M13 9WL. tried simple remedies. Three weeks later he presented at an ophthalmic department with a sore, red right eye.

On examination his visual acuity (VA) was $6 / 6$ in each eye. There was a marked anterior uveitis with focal exudation around a cluster of hairs in the nasal sector of the iris. Approximately 20 intracorneal hairs, which were also surrounded by exudate, were noted. No hairs or nodules were seen in the conjunctival fornices.

The eye was treated with topical atropine $1 \%$ twice daily and prednisolone 2-hourly for 3 weeks with no significant response. In consequence he was examined under general anaesthesia, when in addition to the above findings posterior synechiae of the nasal pupillary border and peripheral anterior synechiae in the same sector were observed. Six hairs were seen in the anteronasal vitreous. An attempt was made to remove some of the intracorneal hairs. This proved difficult because of their extreme friability, and few were extracted. Subsequent addition of systemic steroid therapy ( $5 \mathrm{mg}$ prednisolone 3 times a day) over 2 months failed to control the inflammation and the patient was referred to the Royal Eye Hospital, 6 months after the initial injury.

At this time he had an irritable right eye, with ciliary injection, flare, and cells in the anterior chamber. Four setae were identified within the corneal stroma, and another 3 were embedded in focal exudate on the posterior corneal surface. Ten more were seen lodged in the nasal iris and adjacent trabecular band (Fig. 1). A further hair was found in 


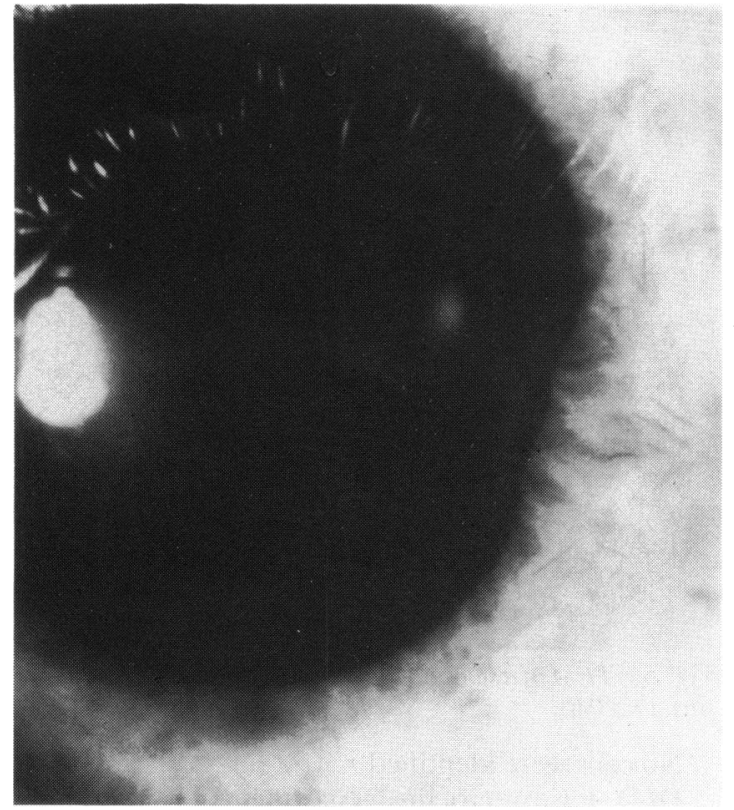

Fig. 1 Slit-lamp photograph of anterior segment showing collection of hairs on nasal iris.

the posterior cortex of the nasal quadrant of the lens. Fundus examination was limited by photophobia, but his visual acuity (VA) remained $6 / 6$.

In view of the failure of medical treatment and early evidence of side effects from the steroids it was decided to attempt surgical removal of as many of the hairs as possible. Under general anaesthesia a reverse slope limbal incision was made in the nasal cornea, and sodium hyaluronidate was instilled to maintain the anterior chamber. Fine straight suture-tying forceps were used to remove 10 hairs from the nasal iris and angle. A further hair was removed from the

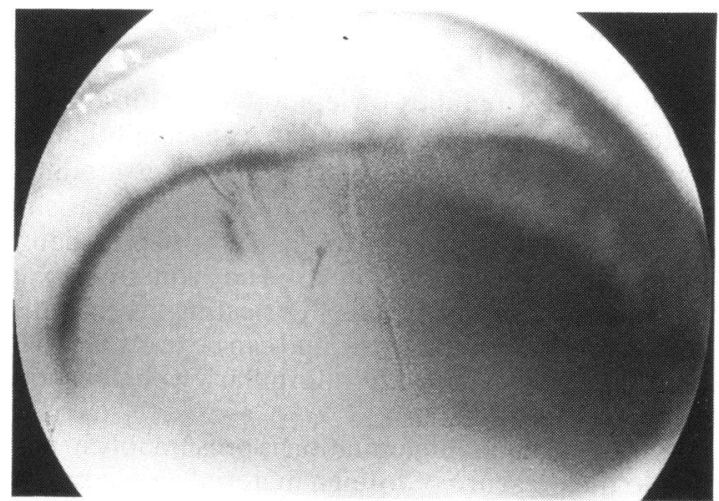

Fig. 2 Retroillumination to show hairs in anterior nasal vitreous. corneal endothelium adjacent to the wound, which was then closed with $10 / 0$ nylon. A second smaller limbal incision was made at 7 o'clock, and 2 further hairs were dislodged and aspirated from the inferior corneal endothelium with a burred hypodermic needle carried on a $2 \mathrm{ml}$ syringe.

Several subsequent minor episodes of anterior uveitis responded easily to mydriatics and topical steroids, and the systemic steroids were phased out within 2 weeks.

There remained 4 fragments of setae within the corneal stroma, one in the posterior lens cortex, 8 in the anterior nasal vitreous (Fig. 2), and one in the posterior vitreous overlying the macula.

Two weeks later a patch of retinochoroiditis was seen below and temporal to the macula presumably related to the hair that had been seen in the adjacent posterior vitreous. There was no visual disturbance, and fluorescein angiography confirmed a window defect. VA remained $6 / 6$.

By May 1983, 9 months after the injury, the remaining hairs in the cornea were barely visible and there was no residual inflammation at their site. Specular microscopy (Keeler-Pocklington-Konan) showed pooled mean central endothelial cell areas of $279( \pm 64) \mu \mathrm{m}^{2}$ in the affected eye and $274( \pm 54) \mu \mathrm{m}^{2}$ in the other eye with normal distributions of cell size. The mean cell counts were $3585 \mathrm{~mm}^{2}$ in the affected eye and $3655 \mathrm{~mm}^{2}$ in the other eye. The setae in the anterior vitreous and lens cortex were in the same position and of variable calibre. One appeared fractured. Some showed mild envelopement in presumed exudate.

\section{ELECTRON MICROSCOPY}

Technical details. After removal from the eye the hairs were placed on a cellulose sponge and fixed in cacodylate buffered glutaraldehyde. For scanning electron microscopy (SEM) pieces of sponge bearing the hairs were snipped off and attached to copper tape stuck to an aluminium stub by silver dag adhesive paint. After drying at $37^{\circ} \mathrm{C}$ they were sputter coated with a layer of gold $60 \mathrm{~nm}$ thick. SEM was carried out on a Cambridge Stereoscan S410 at either 5 or $6 \mathrm{kV}$. For transmission electron microscopy (TEM) a hair was embedded in Araldite and sectioned with difficulty with a glass knife.

$S E M$ findings. The surface of the hairs was characterised by the presence of regularly spaced, sharply pointed, triangular spines angled at about $30^{\circ}$ to the surface and aligned in the same direction. The lengths of hair available for examination did not show perceptible tapering so that the direction in which the spines pointed could not be ascertained, but it is known that the spines are directed towards the tip and not the base. ${ }^{7}$ Numerous round lacunae were 


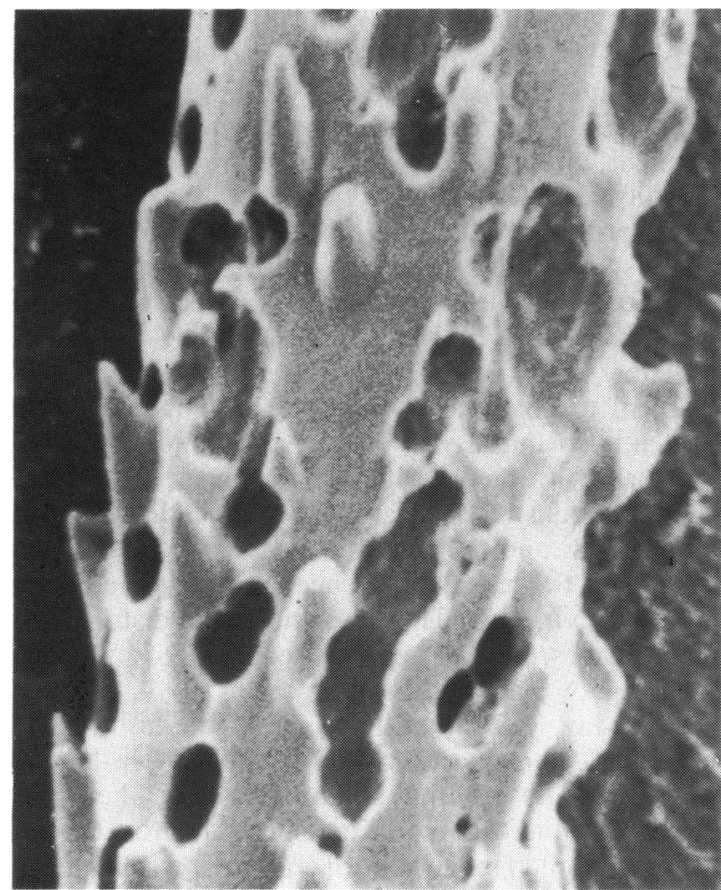

Fig. 3 SEM of surface of a seta showing spines and coalescing rounded lacunae. $(\times 5400)$.

seen in the surface of the setae. These were tending to coalesce (Fig. 3).

Some of the setae appeared to be coated with a smooth layer which had the effect of burying the spines and filling the holes (Fig. 4).

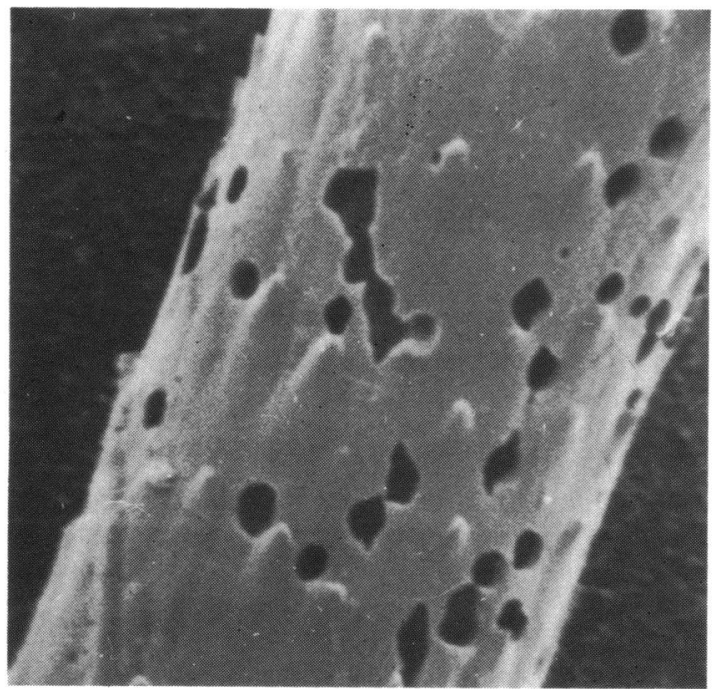

Fig. 4 SEM of surface of a seta coated with a smooth layer which is tending to fill the lacunae and bury the spines. (×4065).

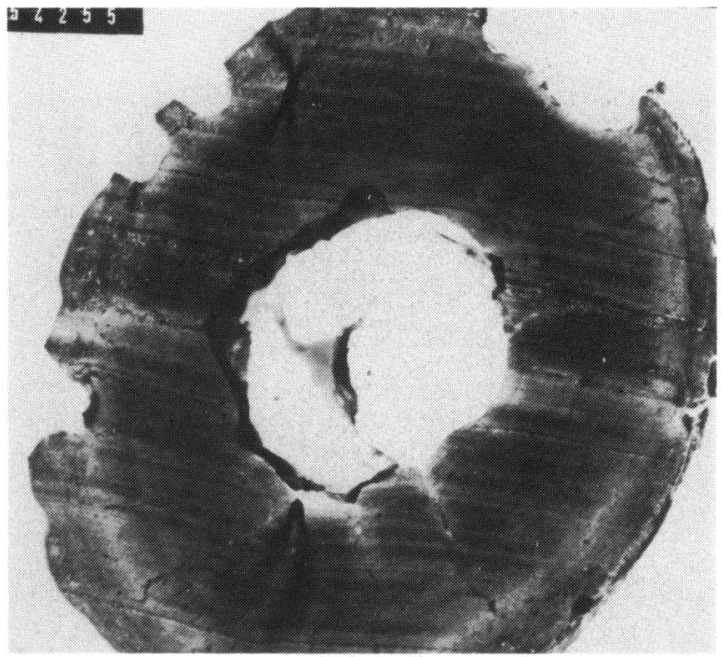

Fig. 5 TEM of a seta showing tubular structure and surface pits. $(\times 5380)$.

No cells were identified.

Dr D. J. Carter, of the Department of Entomology, British Museum (Natural History), kindly examined the SEM pictures of the setae and identified them as probably derived from a caterpillar of the moth family Lymantriidae, and thought they showed evidence of enzymatic degradation.

TEM findings. The bristles were approximately 50 $\mu \mathrm{m}$ in diameter and had a tubular structure. The wall of the tube is composed of chitin, which is a homogeneously electron dense material. The lumen of the tube contained more electron lucent structureless material. The holes in the surface observed by TEM are seen to be relatively shallow (Fig. 5). The external surface is seen to be coated by layers of electron dense material separated by a narrow clear space with a central dark band (Fig. 6). No cells were identified.

\section{Discussion}

Members of 4 families of lepidoptera with a world wide distribution are known to cause ophthalmia nodosa. The Lymantriidae larvae have a modified single hair type with setose hairs in groups arising from cuticular cups or with hairs borne in dense groups on tussocks or tubercles. They contain a toxin secreted by dermal glands. Urticating hairs are a primary defence mechanism and can be transferred to humans by contact with caterpillar, web, cocoon, moth, or egg mass.'

The intraocular inflammation is presumably in part due to the presence of foreign material and in part to the effect of the urticating toxin. ${ }^{8}$ Chemical analysis of the urticating toxin shows a small fraction of water 


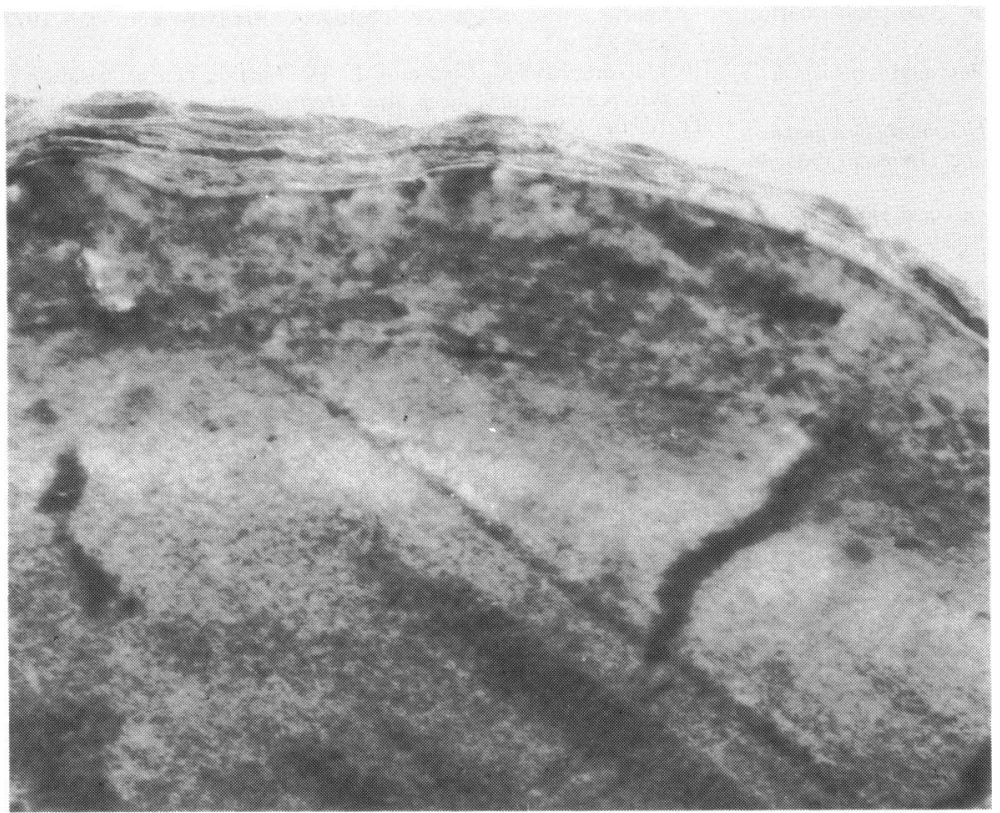

Fig. 6 TEM of surface of a seta showing deposition of layers of material of variable electron density. $(\times 32360)$.

soluble protein with esterase, protease, and phospholipase activity. ${ }^{9}$ The material can also give rise to IgG antibodies in rabbits. ${ }^{10}$

The known propensity of the setae of caterpillars to enter and migrate within the eye in ophthalmia nodosa is easily understood from the SEM appearance of the spines on the setae, which are spaced regularly on the surface with their tips aligned in the same direction. As recognised by Gundersen et al. ${ }^{7}$ the changes in shape of the envelope of the eye during versions must induce progressive inward propulsion of any setae the spines of which are directed towards the surface of the globe. The observed cessation of movement may be explained by the burial of the spines when the shaft becomes coated in exudate (Fig. 4). It is known that both tear and macrophage lysozyme can break down (fungal) chitin (Bron A, personal communication), and thus it appears possible that enzymatic degradation may also contribute to blunting them. An alternative method of propulsion proposed by Ascher, " which was that cellular exudate accumulating at the broken end of the hair pushed it along in the direction of its tip, is not supported by our observations. We saw that the exudates were uniformly distributed along the shafts of the intraocular fragments, which were cylindrical and without discernible tips.

Of 4 previously reported cases in the British literature 3 resolved spontaneously. In one of these ${ }^{12}$ only the conjunctiva was involved. In a further $2^{1314}$ the hairs were intracorneal. The fourth case, in which hairs were seen on the surface of the iris, came to enucleation for intractable endophthalmitis. ${ }^{15}$

Two cases have been treated by iridectomy for hairs embedded in the iris. In one of these the treatment was apparently effective. ${ }^{16}$ In the other the affected eye had to be enucleated for intractable endophthalmitis. ${ }^{7}$ In another case ${ }^{17}$ forceps were introduced into the anterior chamber to remove a hair which had reached the posterior corneal surface. Though there was some doubt as to whether the hair was removed, the eye settled.

Our success in controlling the destructive uveitis, which had proved resistant to medical treatment, by surgical removal of those setae accessible to an anterior approach is encouraging. Indeed, this appears to be the first time caterpillar setae have been removed successfully from within the globe in a case of ophthalmia nodosa. The use of sodium hyaluronidate to maintain the depth and clarity of the anterior chamber was crucial in making the procedure possible and safe to the corneal endothelium.

We wish to thank Mr B. Freeman, FRCS, for referring the patient and for providing invaluable information concerning the course of the disease prior to referral. We are most grateful to Miss B. Enoch, $\mathrm{Mr} \mathrm{M}$. English, and Dr S. Wallis for reporting their observations, and are indebted to Mrs L. A. Thomas for skilled technical assistance and to Miss Terina Chan for the endothelial counts.

\section{References}

1 Picarelli ZP, Valle JR. In Buccherl W, Dculofeu V, Buckley EE, eds. Venomous animals and their venoms. New York: Academic Press, 1971. 
2 Lyte C. Sir Joseph Banks. Newton Abbot: David and Charles, 1980 .

3 Blair CP. The browntail moth. its caterpillar and their rash. Clin Exp Dermatol 1979; 4: 215-22.

4 Schwann J. Dermatitis duc to caterpiliar Thaumatopoea pinivora and their epidemiological significance. Przegl Dermatol 1961; 48: 415-22.

5 Akhand AH. Caterpillar dermatitis. JPMA 1969; 19: 65-8.

6 Pagenstecher H. Interessante Präparate von eindringen Conjunctiva und dic Iris mit daran sich bildenden tuberkelartigen Knötchen. Ber Dtsch Ophthalmol Ges 1883; 15: 176.

7 Gundersen T, Heath P. Garron LK. Ophthalmia Nodosa. Trans Am Ophthalmol Soc 1945; 48: 151-67.

8 Tyzzer EE. The pathology of the browntail moth dermatitis. $J$ Med Res 19(1)7: 16: 43-64.

9 De Jong MCJM, Bleumink E. Investigative studies of the dermatitis caused by the larva of the browntailed moth, Euproctis Chrysorrhoea L. (Lepidoptera, Lvmantriidae). III. Chemical analysis of skin-reactive substances. Arch Dermatol Res 1977; 259: $247-62$.

10 De Jong MCJM, Blcumink E. IV. Further characterisation of skin-reactive substances. Arch Dermatol Res 1977; 259: 263-81.

11 Ascher KW. Mechanism of locomotion observed on caterpillar hairs. Am J Ophthalmol 1966; 65: 354-5.

12 Lawford JB. Ophthalmia nodosa. Trans Ophthalmol Soc UK 1895; 15: 210-30

13 Moore RF. Caterpillar hair ophthalmitis (ophthalmia nodosa). BrJ Ophthalmol 1929; 13: 57-60).

14 Watson PG, Scvel D. Ophthalmia nodosa. Br J Ophthalmol 1966; 50: 209-17.

15 Corkey JA. Ophthalmia nodosa duc to caterpillar hairs. $\mathrm{Br} J$ Ophthalmol 1955 39: 301-6.

16 Weiss L. Ein Fall von schwerer Regenbogenhautentzundung hervorgerufen durch in das Augeninnere cingedrungenc Raupenhaarc. Arch Augenheilkd 1889; 20: 341.

17 Igersheimer J. Dic Entfernung eines Raupenhaare aus der Vorderkammer. Klin Monatshl Augenheilkd 1927; 78: 814-5. 